\title{
フーリエ変換マイクロ波分光法 一新しい可能性を秘めたマイクロ波分光法一
}

\author{
遠 藤 泰 樹 \\ 東京大学教着学部 東京都目黒区駒場 3-8-1（兵153） \\ (1995年 5 月 7 日 受理)
}

Fourier-Transform Microwave Specroscopy.

A microwave spectroscopic method with new possibility

\section{Yasuki ENDO}

Department of Pure and Applied Sciences, College of Arts and Sciences, The University of Tokyo, Komaba, Meguro-ku, Tokyo 153

(Received May 7, 1995)

\section{1. はじめに}

マイクロ波分光法は，すでに長い歴史を持ち，技術的 には成熟した分光法であると考えられてきた．特にクラ イストロンのような発振器やマイクロ波コンポーネント の入手が容易なセンチ波領域は早くより活発な研究が行 われ，現在ではこの波長域で新しい技術的な可能性や， 魅力的な研究テーマを見いだすのは困難になりつつあっ た。そのため，マイクロ波分光法による研究の最前線 は，上り周波数の高いミリ波やサブミリ波領域の分光へ と向かっていた．特に，最近になってミリ波・サブミリ 波領域の優れた倍周器や, 発振器が比較的容易に手には いるようになったこともあり，数 $100 \mathrm{GHz}$ から1000 $\mathrm{GHz}$ 位までの周波数領域の分光器で, かなり性能の高 いものが作られるようになってきている.

技術的には高度なものが要求されコストがかかるにも かかわらず，より高い周波数での分光が積極的に試みら れている一つの理由は, マイクロ波の遷移では, 吸収強 度が遷移周波数の $2 \sim 3$ 乗に比例して強くなることにあ る.このため，高い周波数領域では極めて高感度の分光 器を作ることができ，特に不安定分子のように生成の困
難な分子種の分光に威力を発揮する．しかしながら，こ の方法による感度の向上にもある限界が存在する. 研究 対象とする分子がある程度大きくなると，ミリ波や，サ ブミリ波の領域では観測可能な遷移が回転の量子数 $J$ の 大きな状態間の遷移になる，そのような場合，マイクロ 波分光で通常は期待される超微細分裂を観測できないと か, 観測可能な遷移の数が増えて解析が困難になるなど の問題を生じる. また，分子のサイズに比べ周波数が高 すぎると，エネルギーの高い準位間の遷移になり，ボル ッマン因子の影響で感度の上昇が相殺されてしまうこと となる.そのため, センチ波の領域でこれまでの伝統的 な吸収分光法に变わる新しい可能性を持つ分光法が, 望 まれていた．技術的にはすでに開発の余地が少ないと考 えられていたセンチ波の領域で，そのような可能性を秘 めた新しい分光法として, フーリエ変換マイクロ波分光 法が注目を浴びるようになってきているのである.

本稿では, このフーリエ変換マイクロ波分光法の原理 と実際に作られている装置について説明し，どのような 研究に応用されているか, 更に, 今後どのような可能性 があるかを述べたい。 


\section{2.フーリエ変換マイクロ波分光法の動作原理}

マイクロ波領域ではクライストロンや，最近進歩の著 しい半導体の発振器など, 周波数が可変でスペクトル純 度の高いコヒーレントな光源が使えるので, 分解能が分 子自体の線幅で決まるような高分解能分光を容易に実現 できる。一方，この領域では遷移の上側と下側の準位間 のエネルギー差が常温の熱エネルギーに比べて小さく, 準位間の分布数が接近しているため, 赤外分光や可視, 紫外分光の場合と比べ吸収係数が極めて小さくなる.こ のような小さな吸収の変化を観測するために，通常は， 分子自体に变調を掛けるシュタルク変調法が使われる. 周波数が高くなってミリ波, サブミリ波の領域になる と, 分布数の差が比較的大きくなり, 吸収係数も増して くるので, より直接的に吸収の変化を観測する光源変調 法を使うことができるようになるが，センチ波の領域で は実用的ではない、シュタルク変調法は, 分子自体があ る程度以上の永久双極子モーメントを持っている必要が あることや，吸収セルの中に電極を挿入し，電压をかけ る必要があること等のため，分光の対象になるのは主と して極性の比較的大きな安定分子に限られてきた．光源 がコヒーレントであるという特性を積極的に利用して, シュタルク変調法の限界を打破し，より高い感度を得る ことのできる分光法として考え出されたのがフーリ工変 換マイクロ波分光法である.

この方法は，核磁気共鳴法で普通に使われている方 法, すなわちフーリ工変換型 NMR 法, に直接対応す るものである. 図 1 に示すように, マイクロ波のパル 又を分子に照射すると，分子系には㧍互いに位相の揃っ た分極が生じる．外部からの電界が消えると，その分極 が二つの状態のエネルギー差に等しい振動数のマイクロ 波を輻射する。マイクロ波の輻射は，分子系の緩和時間 に対応した減衰振動となって観測され，これを自由減衰 振動 (Free Induction Decay, FID) と呼ぶ.この FID 信号が最も強くなるのは，マイクロ波の電界強度とパル ス幅の積が $\pi / 2$ パルスの条件を満たすときである $(\mu E \Delta t / \hbar=\pi / 2)$. ここで分極を生じさせるマイクロ波 のパルス幅が充分に短ければ，その周波数は分子の遷移 周波数に必ずしも正確に一致している必要はない。一 方，分極した分子系が輻射するマイクロ波の周波数は， 正確に分子の遷移周波数に一致しているので，その差の 周波数を知ることができれば分子自体の遷移周波数を決 定することができる.

この方法では, 分極を起こさせるための入射マイクロ 波パルスの影響をうまく除くことが出来れば，観測する

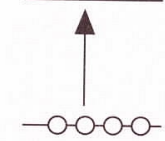

$\pi / 2$ パルスによる

励起

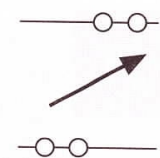

分子系に分極か 生しる

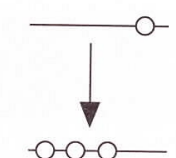

FID 信号の

放出 この FID 信号索 時間軸の信号として 取り込みフーリ工変强

図 1 フーリエ変換マイクロ波分光法の原理

のは分子自体の発するマイクロ波なので, 吸収分光法の ようにマイクロ波源のノイズや, 吸收セル内でのマイク ロ波の透過の周波数依存性などがスペクトルの観測を脄 害しない、また，この方法では，入射するマイク口波パ ルスのパルス幅の逆数に比例する周波数領域を一度に観 測できる．そのため，一定の周波数範囲の分光を行なう 場合, 連続的に周波数を変えながら吸収を観測する通常 の分光法に比べ，理論的にはより高い感度を得ることが 出来る. 実際, フーリ工変換法で得られる $S / N$ 比上通 常の吸収分光法で得られる $S / N$ 比との間には, 双方の 観測が理論的に行なわれるとすると，次の上うな関係式 が成り立つ1).

$(S / N)_{\text {FTMW }} /(S / N)_{\text {CWabs }} \fallingdotseq 2(F / \Delta)^{1 / 2}$

ここで，Fはフーリエ変換分光法により一度に観測でき る周波数領域の幅で，これはほぼ入射マイクロ波のパル ス幅の逆数に詨応する. である. 吸収線の幅は実験条件で決まるので, フーリエ 変換法で大幅に感度を改善するには, 入射マイクロ波パ ルスの幅を短くしてできるたけ広い領域を観測するよう にするとよい、このとき, 遷移に対しては $\pi / 2$ パルス の条件を満たす必要があるので, 広い範囲を一度の観測 するには大きなマイクロ波のピークパワーが必要とな る. 特に分子の双極子モーメントが小さい場合には, 狭 いパルス幅でこの条件を満たすのは困難になり，観湘可 能な周波数範囲を余り広く取ることはできない，ところ が：シュルク変調法で双極子モーメントの小さな分子 の吸収を観測する場合にも，分子に対して変調がかかり にくくなり実効的な感度が大きく低下する，そのため， 実際に実験条件で比較すると双極子七一メントの小さな 分子の分光に対しても, フーリエ変換分光法の方が有利 である。

更にフーリエ変換分光法では，マイクロ波の吸収分光 法で問題になる吸収の飽和効果が存在しないため, 試料 の圧力を充分低くして測定すると，分子のドップラー幅 
で分解能が決まる高分解能分光が可能になる. 一方, 分 子からの非常に弱いマイクロ波輻射を高感度に検出する 必要があるため, 実験装置の構成はやや複雑になる。ま た，入射パルスのパルス幅やマイクロ波の強度などの実 験条件の設定が微妙で, 観測されたスペクトル線の相対 強度などを問題にするときには注意が必要となる。

\section{3. フーリエ変換マイクロ波分光器の実際}

前節で述べたような特徽を持つフーリエ変換マイクロ 波分光法を初めて実現して, 分子の回転スペクトルの観 測が可能であることを示したのは Ekkers と Flygare で ある11. 図 2 に彼らの装置のブロックダイアグラムを示 す。この装置では導波管を吸収セルとして用いている. なるべく広い領域を一度に観測するために，マイクロ波 発振器の出力を TWT アンプで $20 \mathrm{~W}$ に増幅したものを 入射マイクロ波として用いている．これをマイクロ波の スイッチで幅の狭いパルス（パルス幅約 $10 \mathrm{~ns}$ ) に成形 して吸収セルに導入する，分子が放出する FID 信号は 微弱なので，検出にはへテロダイン検波法を用いる。へ テロダイン検波用のミキサーに分極用の強力なマイクロ 波パルスが入って信号観測系を飽和させるのを防ぐため に，導波管の出口側にもう一つマイクロ波スイッチが入 れてある。これは入射パルスが終わった直後に開く、へ テロダイン検波された信号は更に周波数を落として A/ D コンバータに導かれる. A/D コンバータのサンプリ ング周期は20 ns であり, 彼らの装置では40 MHzの領 域を一時に観測できた，前節で示した式に対応する感度 の改善を得るためには、このパルス的な観測を FID 信 号の減衰時間に対応する周期で繰り返し，データを積算 する必要がある。そのため，彼らは特別に 1 ビットの $\mathrm{A} / \mathrm{D}$ 変換器と高速積算回路を製作した．繰り返し周期

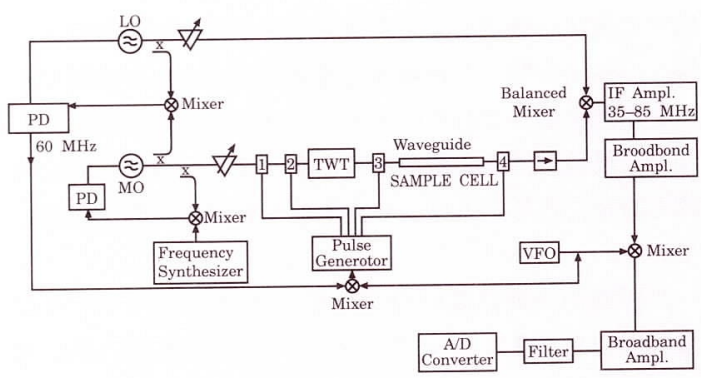

図 2 導波管型フーリエ変換マイクロ波分光器の プロック図(文献 1)より).

図で1-4はマイクロ波のスイッチであり， $\mathrm{PD}$ とあるのは周波数安定化装置.
としては $30 \mathrm{kHz}$ を得ており, 結果として観測時間当り の感度がシュタルク分光法に比べかなり高くできること を示した.

導波管の吸収セルを用いたフーリエ変換マイクロ波分 光器を発表してから数年の後, Flygareらはファブリー ペロー型の共振器を用いた新しい形式の分光器を発表し $た^{2)}$. 導波管を使用したフーリエ変換型分光器は, シュ タルク変調型の分光器に比ベ, 高感度であるにもかかわ らず, 装置の特にマイクロ波回りとデータ取り込みの部 分が複雑になる上に，導波管を吸収セルに用いたために 分光の対象が安定分子に限られた。 そのため, シュタル ク変調法による分光が困難な双極子モーメントの小さな 安定分子以外に新しい研究テーマを見いたすことができ ず,それほどの普及をしなかった。これに対してファプ リーペロー型の共振器を使用した分光器は, 超音速ピー ム法と組み合わせてビーム中の分子のスペクトルを観測 できる装置であり，特に分子間錯体の研究に威力を発揮 し広く注目を集めた．現在では，フーリ工変換型のマイ クロ波分光器という場合は, ほとんどこの型のものを指 す.

この形式の分光器では, 導波管の吸収セルの中にマイ クロ波パルスを照射して吸収セル中に存在する分子に分 極を生じさせる代わりに，図 3 に示すようなファブリー ペロー型の共振器にマイクロ波を照射し, その共振器の 間の分子に分極を起こさせる. 通常, 共振器は直径30 $50 \mathrm{~cm}$ のアルミニウム製の球面鏡 2 枚で構成する．こ の型の共振器では約 10,000 程度の Q 值を得ることがで き, 共振器内の実効的な電界強度を高くできる。そのた

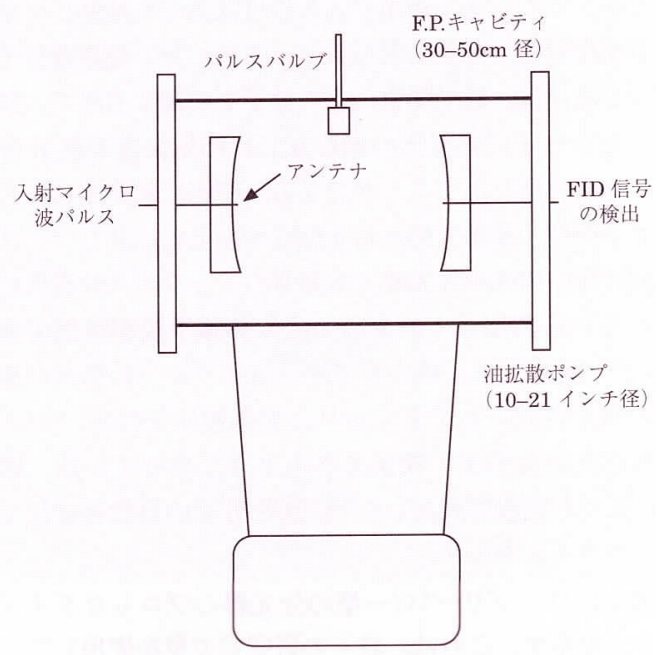

図 3 ファブリーペロー型分光器本体の概念図. 
め，1デバイ程度の双極子モーメントを持つ分子に対し ては, 入射マイクロ波のパワーが $1 \mathrm{~mW}$ 程度であれば 十分に $\pi / 2$ パルスの条件を満たすことが出来る。一方, 共振器を用いているため一度に分極を起こさせることの できる周波数範囲はかなり狭い（Qが10,000程度ある ので, $10 \mathrm{GHz}$ では分子を分極可能な周波数範囲は共振 器の共振周波数の前後 $1 \mathrm{MHz}$ 程度である). また, 吸 収線の線幅 (フーリ工变換分光法の場合は FID 信号の 持続時間の逆数) が, この共振器の共振幅に比べ充分に 狭くなければならないが，観測可能な周波数範囲があま り広くないので, フーリ工変換法で時間領域の観測をす ることによる感度の改善は, 前節の導波管を用いた装置 の場合に比べるとそれほどではない，一方，観測範囲が 狭いので A/D 変換器のサンプリング周期は250-500 ns 程度で充分である. 更に大出力のマイクロ波増幅器を使 用する必要がないこともあり, 分光器を実現するための エレクトロニクスはかなり簡単になる。これに対し, 吸 収セルに相当する部分は大きな球面鏡を収容して全体を 真空に排気する必要があるため，かなり大がかりにな る.

このファブリーペロー型の分光器の最大の特徵は, 共 振器の間に分子を超音速ビームとして流し, 回転温度が 極めて低い分子のスペクトルを観測できることにある. マイクロ波の領域では, 常温の熱エネルギーに比べ遷移 のエネルギーがずっと小さいため，観測しようとする遷 移の上と下の状態の分布数の差が極めて小さく，通常は このことがこの周波数領域の分光法の感度を制約してい る. 一般の吸収分光法では吸収セルをドライアイスや液 体窒素で冷却するのが有效であり，しばしば用いられて きたが，この方法が適用できるのは低温でも観測に必要 な蒸気圧を持つ分子に限られる. これに対し超音速分子 ビーム法では，断熱膨張により分子を泠却するので，試 料となる分子の蒸気圧の制約無しに回転温度が数 K 程 度の状態を作り出すことができる，実際に超音速ビー人 による冷却の効果で得られる感度の向上には著しい. 比 較的初期の構成の分光器でも通常のシュタルク分光法に 比べると存在比が 1 桁少ない同位体種が観測可能であ っだ). 現在では，後の章で述べるように更に装置の感 度の向上が図られてきており, 大体親分子の $10^{-6}$ 以下 の存在比の成分まで検出できるようになっている. 図 4 に我々の装置で観測した ${ }^{18} \mathrm{O}^{13} \mathrm{CS}$ 分子の自然存在比で のスペクトルを示す.

図 5 にファブリーペロー型の分光器のブロックダイア グラムを示す。これは, 我々の研究室で現在使用してい るものである4). 入射マイク口波は, 導波管型の分光器

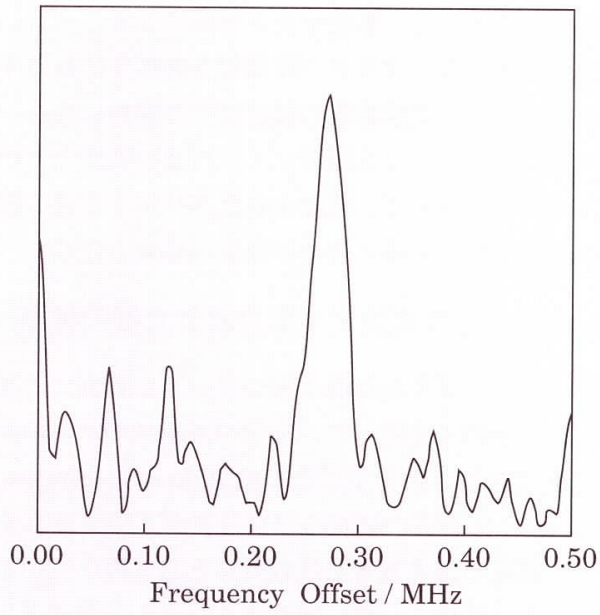

図4 ${ }^{18} \mathrm{O}^{13} \mathrm{CS}$ (天然存在比 $2 \times 10^{-5}$ ) の $\mathrm{J}=1-0$ 遷移のスペクトル.

横軸は中心周波数 $11,381.852 \mathrm{MHz}$ からの才 フセット．1000回の積算（観測時間200秒） 結果をフーリ工変換して得たもの.

の場合のように大出力でめる必要がないので, 50〜100 $\mathrm{mW}$ 程度の出力を持つ $\mathrm{YIG}$ 発振器の出力をそのまま用 いることが出来る. また, 双極子モーメントの大きな分 子の分光に限れば, $1 \mathrm{~mW}$ 程度の出力で充分であるの で, マイクロ波帯の周波数シンセサイザーの出力を用い ることも可能である. 図 6 にこの型の装置での 1 回の 観測のタイミングチャートを示す. 分子を超音速ビーム として噴出するためにパルスバルブを開いてから分子が 共振器内に到着する屯で一定時間待った後, マイクロ波 のパルスを照射して分子を分極させる．マイクロ波パル スの照射直後は, まだ強いマイクロ波の電界が残ってい るので, 多少の遅延時間をとってデータのサンプリング を開始する，後で述べるように，超音速ビームとして噴 出する気体を放電して不安定分子を生成する場合などに は，バルブを開いた後適当な遅延時間をとって放電パル スを印加する。これらのタイミングは, 個々の実験に合 わせて最適化する必要がある. 我々は, デジタル的に時 間を設定できるタイミング発生器を製作し全体を制御し ている。

共振器が十分に高い $\mathrm{Q}$ 值を持つためには, マイクロ 波の出力をうまくファブリーペロ一型の共振器の中に導 くとともに，この共振器から効率的に FID 信号を取り 出す必要がある, 我々の装置では, マイクロ波と共振器 とのカップリングには L 型のアンテナを用いた。その 他の部分はすべてマイクロ波の同軸ケーブルと，これに 


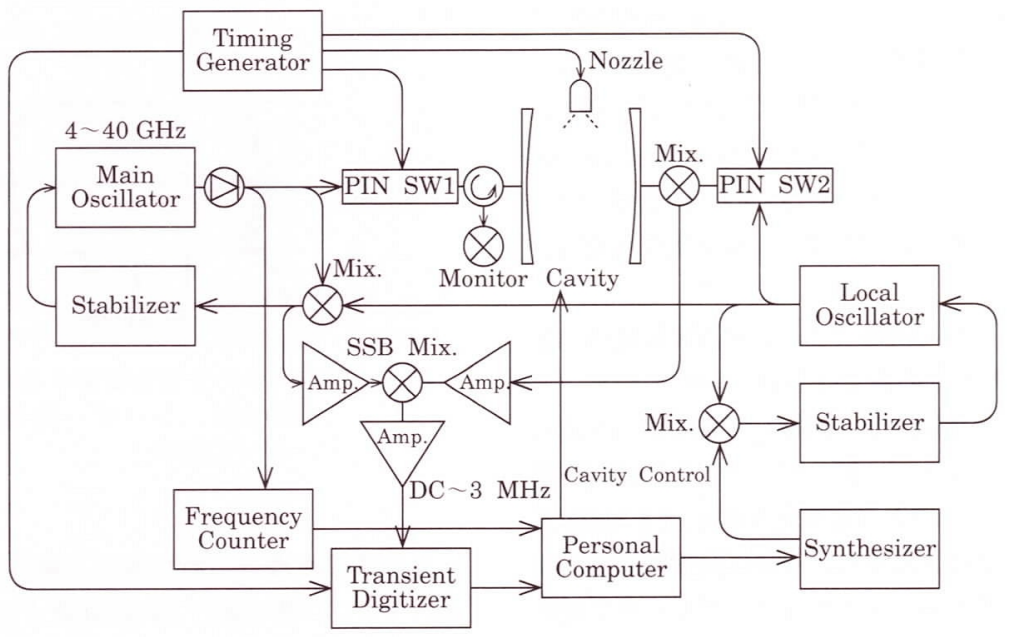

図 5 ファブリーペロー型分光器のプロックダイアグラム

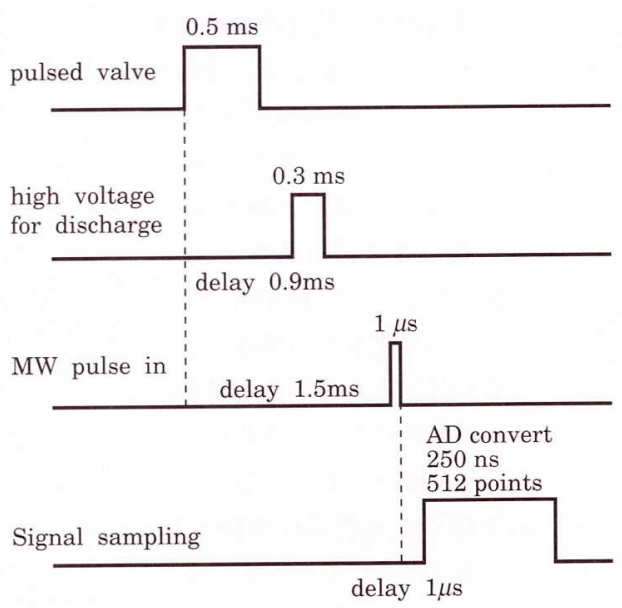

図 6 ファブリーペロー型分光器の 1 回の観測の タイミングチャート

適合したマイクロ波コンポーネントを用いている. L 型 のアンテナは，観測周波数で $1 / 4$ 波長の条件を満たして いるべきなので, 広い周波数領域をこの条件を満たして カバーするためにアンテナを交換可能な構造にして，い くつかの長さの異なるアンテナを用意して最適な長さの ものを使用できるようにしている.

FID 信号をへテロダイン検波してからの信号処理は 導波管型のものとほぼ同じであるが，観測する周波数範 囲が狭いので中間の増幅器の帯域幅は狭くてよい $(2$ $3 \mathrm{MHz})$. また, 信号の $\mathrm{A} / \mathrm{D}$ 変換も, 要求されるサン プリング周期が 250-500 ns 程度なので, 特に高速の A/
D 変換器を使う必要はない。我々の場合は, $50 \mathrm{~ns} の$ 周 期でサンプリングを行い, 前後 5 点の平均を取って 250 nsのサンプリング周期の信号としている.

導波管型のフーリエ変換分光器の場合は, 繰り返し周 波数を上げ観測のデッドタイムを短くして感度の向上を 計る必要があったが，超音速ビームを用いた装置では， 観測の周期はパルスビームの繰り返しによって決まる. この場合には，パルスあたりの分子数をなるべく多くす ることによって実効的な感度を向上させることができる ので，特に速い繰り返しで測定する必要は無い，分子ビ 一ムの温度などの条件が一定であるとし, 真空ポンプの 排気速度も一定であると仮定すると，パルスの繰り返し 周波数を $1 / \mathrm{N}$ 倍すると，パルスあたりの分子数が $\mathrm{N}$ 倍 になるののに対し，積算による $\mathrm{S} / \mathrm{N}$ 比の低下は高々 1 / $\sqrt{\mathrm{N}}$ 倍であるので, 全体としては感度は $\sqrt{\mathrm{N}}$ 倍に向上す ることとなり, 繰り返し周波数は遅いほど有利になる計 算になる，実際には，分子ビームの生成条件などとの関 係で， 2-20 Hz 位の周波数で測定を繰り返すのが普通で ある. 繰り返し周波数がこのように遅いので， A/D 変 換器には市販のトランジェントデジタイザーが使用でき る.積算は $\mathrm{A} / \mathrm{D}$ 変換の終了後にコンピュータにデータ を転送してそこで行う．適当な回数を積算した後，デー タを取り込んだコンピュータで数值的にフーリエ変換を 行い, スペクトルを表示する.

パルスあたりの分子数を多くする方が感度が向上する ので，排気に用いる真空ポンプはできるだけ大きなもの を使用する．通常は，10-21インチの拡散ポンプをファ プリペロー共振器を収容した真空チェンバーに直結して 
排気する．観測領域がノズルの出口から $30 \mathrm{~cm}$ 位離れて いるので，その点で超音速ビームの条件を満たすには， 動作時のチェンバー内の圧力を $10^{-4}$ Torr 以下に保つ必 要がある. 一方, 拡散ポンプのオイルがマイクロ波の伝 搬に影響を及ぼすことはほとんどないので. 冷却したバ ッフルを付けるなど特に真空の質に注意を払う必要はな い.

前述のようにこの型の装置では, 1 回の観測範囲が励 起マイクロ波の周波数の前後 $1 \mathrm{MHz}$ 程度である. た，観測に先立って鏡面間隔を調整して共振器の同調点 に合わせておく必要がある，従って，一定の周波数範囲 の観測を行うには，このような測定を例えば $1 \mathrm{MHz}$ ス テップ毎に繰り返すことになる。一般に共振器の鏡面間 隔をコンピュータ等を用いてステッピングモータで制御 し，共振点がマイクロ波の周波数に追随するようにす る. 非常に弱い吸収線を観測する場合以外は，40-100 パルス程度の積算で充分なことが多いので，大体 1 時 間に100-200 MHzの領域を観測できる.

\section{4. 装置の改良}

この分光法が開発された当初数年の間は，適当な分子 の混合気体を超音速ビームとして噴出することで種々の 新しい分子錯体の分光が可能であったので，装置の感度 を向上するための努力は特に払われてこなかった． 1980年代の終わり頃になって 3 量体以上の分子錯体の 分光や，無極性分子の分子錯体，不安定分子の分光等が 盛んに試みられるようになるのに合わせて，高感度化へ の要求が高まり，そのための様々な工夫が行われるよう になってきた，

Gutowsky ${ }^{5}$ 等は, 1 つの気体のパルスに対して多数 のマイクロ波パルスを当てて FID 信号を観測し，全体 としての観測時間を節約することを試みた。通常のパル スバルブを用いた場合，気体はほほ 1 ミリ秒位の間噴 出している.これに対し，一つのマイクロ波に対し， FID 信号の持続時間は，100マイクロ秒以下である. 彼 らは, 1 回の気体パルスに対し, 最大 16 パルスのマイク ロ波を当て，FID を観測できるようにして積算回数を 増し，感度の向上を図った。

また，著しい感度の向上の得られた方法として，超音 速ビームを通常の配置のように共振器の横から噴出する のではなく, 図 7 に示すようにマイクロ波の進行方向 に噴出する方法がある ${ }^{6)}$. 試料を共振器の横から噴出し た場合には, 気体のジェットがマイクロ波の進行方向に 対し前後に広がったものを観測することとなり，これに よるドップラー広がりが生じ, 信号のピーク強度が小さ

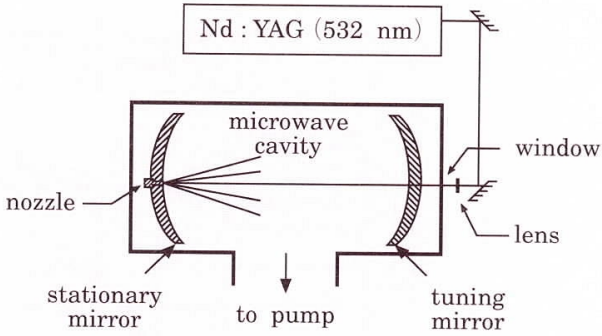

図 7 軸方向から分子を噴射する分光器の例.

この場合は、レーザー蒸発法と組み合わせ ている(文献30)）。

くなってしまう。これに対し, 軸方向に噴出した場合 は，マイクロ波の進行万向に直進する成分たけを観測す るためドップラー広がりが小さくなり, 信号強度が増大 する。実際，この方法でほぼ 1 桁の感度の向上が見ら れることが報告されている，実際には共振器の中のマイ クロ波は定在波なので，気体の進行速度に対し正・負両 側のドップラーシフトが生じる．そのため，観測される スペクトルは，一つの吸収線に対して幅の狭い 2 本の ピークを持つものとなる。横方向噴射の場合，線幅が 20-30 kHzであるのに対し，軸方向の噴射の場合のス ペクトル線の幅は $2-3 \mathrm{kHz}$ 程度である。実用上は，共 振器の球面鏡の中心から気体を噴出させる必要があるた め, 不安定分子の分光を行う場合のように，ノズルに様 々なものを取り付ける必要がある場合には，このような 構成を取るのが困難になる，そのため，安定分子の分光 以外にはまだ余り試みられていない。

一方，FID 信号の処理系にも様々な工夫が行われる ようになってきている，そのひとつが，シングルサイド バンド検出である。通常，FID 信号は 2 段のへテロダ イン検波をして励起マイクロ波とのビート信号の形で取 り出す．これを時間軸でサンプリングして, フーリエ変 換をパワースペクトルとして表示する。このようにして 得られるのは, 励起マイクロ波からの差の絶対值の位置 にピークを持つスペクトルである。そのため，観測され たスペクトルそのままでは, 吸収線が励起マイクロ波の 高周波側にあったのか低周波側にあったかを決定するこ とはできない。また両側の雑音成分が同じ周波数の点に に重なって観測されることとなり， $\mathrm{S} / \mathrm{N}$ 比の上からも 好ましくない，励起マイクロ波の高周波側と低周波側の 信号を分離して観測できれば，スペクトルの解析が容易 になるだけでなく，感度の向上も期待できる：これを実 現するひとつの方法が，Quadrature Mixer と呼ばれる ミキサーを用いるもので，これを用いると図８のよう 


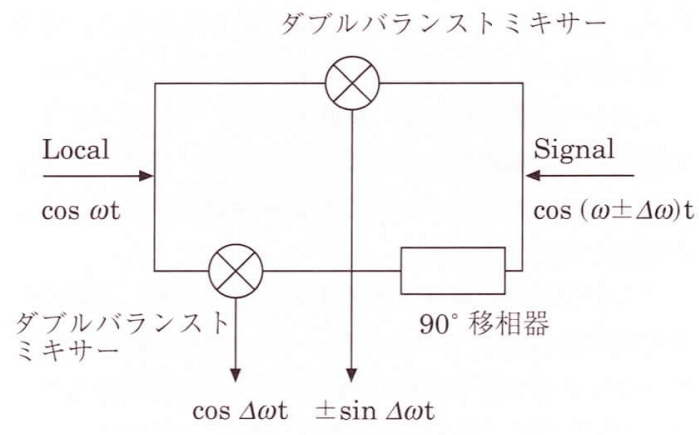

図 8 Quadrature Mixer の原理図

に $\sin と \cos の 2$ 成分が検波出力として取り出せるの で，これを複素フーリ工変換して高周波側と低周波側の 信号を分別することができる4). 更に別の方法としては， 2 段目の周波数变換で, ゼロビートを取る代わりに数 $\mathrm{MHz}$ の周波数の位置に信号を落とし、これをサンプリ ングしてフーリエ変換する方法がある。この場合, 局部 発振信号の位相が元のマイクロ波に対し，一定の関係に 㐫る必要がある7

初期の頃の作られた装置の観測可能な周波数範用は, 殆どが 8-18 GHz であった。この理由の一つは，この型 の分光器を実現するのに必要なマイクロ波スイッチやミ キサー, 発振器など様々なコンポーネントが手に入りや すいことである．また，分子錯体の回転定数は一般にか

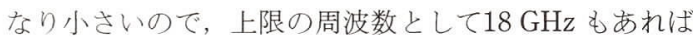
充分なだけの回転線を観測できることもあった。一方， より低い周波数の観測は，装置的な問題は少ないが，一 般に検出感度が低くなってしまう。最近の様々な工夫に より，検出感度の向上が図られてきたので，2 GHz 程 度の低い周波数の信号まで観測できるようになってきて いる8)。この場合には，共振器の鏡面のサイズを大きく する必要がある.高周波側に更に観測可能な周波数を伸 ばすことは，回転定数が比較的小さくなる分子錯体の分 光に関しては，それほどの必然性はないが，単体の不安 定分子のスペクトルを観測する上では新しい可能性を開 く. 最近になって，より高い周波数の観測できるように 装置を改良する試みがなされるようになってきた，現在 のところ， $40 \mathrm{GHz}$ までをカバーする装置が作られてい る ${ }^{9}$. この周波数領域までは, 最近のマイクロ波技術の 進歩により同軸型の様々なマイクロ波コンポーネントが 手にはいるようになったので，より低い周波数領域とあ まり大きな変更なく周波数を拡張できるが，これ以上の 周波数領域への拡張には, 導波管のマイクロ波コンポー ネントを使う必要が出てくるので，マイクロ波の引き回
しなどの点で困難が大きくなってくる．

\section{5. 極性分子の分子錯体の分光}

パルス超音速分子ビーム法と組み合わせたフーリエ変 換分光器は, 超音速ビーム法が分子錯体の分光に適して いることから数多くの分子錯体の分光に適用されてきて 抢り, 現在でもこの分光法の適用分野として重要な位置 を占めている. 実際, Flygare らが, この型の分光器の 開発の報告に先たっって $\mathrm{Kr}-\mathrm{HCl} の$ 分光結果を報告し $た^{100}$ のを始めとして, 次々と各種の分子錯体の分光結 果を報告しこの分光法の威力を示したことでこの分光法 が注目されるようになったのである.

これまでにこの方法で分光された分子錯体は，比較的 強い水素結合をしている八ロゲン化水素を含む錯体にと どまらず広い範囲におよんでいる、フーリ工変換分光法 が開発されて 15 年あまりの研究の歴史の中で, 安定分 子の 2 量体は膨大な分光結果が積及重ねられてきて扮 り，それら一つ一つについてここで論じるのはもはや不 可能といえるほどになっている.フーリ工変換マイクロ 波分光によって得られる結果, 特に各種同位体種の精度 の高い回転定数や, 遠心力歪久定数, 核四重極子相互作 用定数などは,これら様々な系の分子間相互作用ポテン シャルの決定に重要な役割を果たしている.

分子錯体の分光が，分子間相互作用に対して重要な寄 与をすることを考えるとき， 2 量体以上の多量体のスペ クトルの観測も一つの大きなテーマになる，最初にこの 分光法で， 3 量体以上の多量体のスペクトルを観測した のは, Gutowsky 等のグループである. 彼らは, $\mathrm{Ar}_{2}$. $\mathrm{HF}$ のスペクトルの観測を報告した後 ${ }^{11)}$ ，一連の系の分 光を行い， 5 量体である $\mathrm{Ar}_{4}-\mathrm{HF}^{12)}$ の観測までを報告し ている. 彼らは又, $\mathrm{HCN}$ の直線型の 3 量体のスペクト ルなども報告しているが13), 最近の興味深い結果とし ては, $(\mathrm{Ar})_{\mathrm{m}}\left(\mathrm{H}_{2} \mathrm{O}\right)_{\mathrm{n}}$ の型の多量体のスペクトルの観測 と，その構造の報告 ${ }^{14)}$ が挙げられる.

\section{6. 無極性分子同士の分子錯体の分光}

マイクロ波分光法は, 分子. 分子錯体の純回転スペク トルを観測するのであるから，永久双極子モ一メントが 存在しない系は, 観測対象にならない, ところが, 分子 間相互作用に興味を持たれている系の中には, 無極性分 子の組み合わせからなる錯体も数多く存在する，例え ば, 二酸化炭素や，アセチレン，窒素，酸素分子などが ある、この上うな無極性分子同士，あるいは，これら無 極性分子と希ガスとの錯体でも，実際には，錯体形成に よる誘起効果により小さな双極子モーメントが生じる. 
フーリエ変換マイクロ波分光器では，入射マイクロ波の パワーを増してマイクロ波の電界強度を上げてやれば, このように双極子モーメントの小さな系の分光も可能と なる.

このような分子の例として, 最初にフーリエ変換マイ クロ波分光法で, スペクトルの観測された例は，希ガス $-\mathrm{CO}_{2}$ の系である15)。我々は, 同様な系である $\mathrm{Hg}-\mathrm{CO}_{2}$ のスペクトルを観測した ${ }^{16)}$. その後, $\mathrm{Hg}$ との錯体たけ ではなく一連の希ガス原子と $\mathrm{CO}_{2}$ の錯体のスペクトル も観測して, これら一連の系の分子間相互作用に関して 系統的な議論を行った17)。 また，図 9 に示すのは，我 々の研究室で観湘した類似の系である $\mathrm{Ar}-\mathrm{HCCH}$ 錯体 のスペクトルである18). MBER 法によるシュタルク効 果の測定では，この分子の双極子モーメントは0.027デ バテとかなり小さい值を持つことが報告されていた19).

無極性分子のなかでも, 分子間相互作用に関しとりわ け重要性があると考えられる分子としてベンゼンがあ る、これまでにもベンゼンと極性分子の錯体は，様々な 系が研究されている. 誘起双極子モーメントしか存在し ない無極性な系である希ガ久との錯体は，Bauder らの グループにより初めて観測された20). 彼らの結果によ ると, この系は対象コマのスペクトルパターンを示し， 希ガス原子はベンゼンの 6 回軸上にあると結論された. 我々も類似の系としてベンゼンと窒素とのファンデアワ 一ルス錯体の純回転スペクトルを観測した ${ }^{21)}$ 。この場

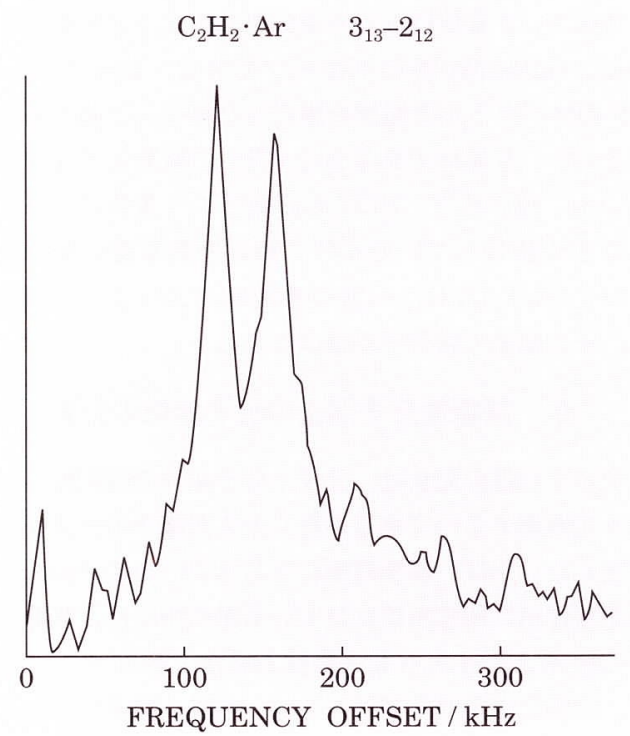

図 $9 \mathrm{CH}_{2} \mathrm{H}_{2}-\mathrm{Ar}$ の $3_{12}-2_{12}$ 遷移のスペクトル (中 心周波数11,334.214 MHz) 400 回の積算結 果をフーリ工変換した（文献18））。
合も, 窒素分子はベンゼンの 6 回軸上にあるが, 窒素 の分子軸はベンゼン面と並行になっている. そのため, ベンゼン窒素の系では, 窒素分子が, ベンゼンに対し て相対的な回転運動をすることができる. 実際, 観測さ れたスペクトルパターンはこの回転運動を反映してかな り複雑なものであった。

ベンゼンを含む錯体で最も重要と考えられ，広範な分 野で興味を持たれているのが，ベンゼン 2 量体である. 2 つのベンゼン分子が相対的にどのような配向をしてい るかに関しては, 様々な説があり, 確定していなかった. 2 つのベンゼン分子が平行になっている場合には, 対称 性から誘起双極子モーメントは生じず，マイクロ波スペ クトルの観測は不可能である. Klemperer 等は, MBER 法による実験から少なくともベンゼン 2 量体は 双極子モーメントを持つ，すなわち 2 つのベンゼン分 子は, $\mathrm{T}$ 型の配向をしていると結論していた22).

Gutowsky らのグループは, フーリ工变換マイクロ波 分光法により初めてベンゼン 2 量体の純回転スペクト 儿を観測し，実際に T 型が安定な配向であることを示 した8).

このベンゼン 2 量体は, 極めて複雑な内部運動を持 つ. $\mathrm{T}$ 型が最も安定な配向であるとすると， 2 つのベン ゼン分子の間には互いの役割を交換するギャー運動が可 能になる.この運動は, スペクトル線に分裂を与える. 更に，それぞれのベンゼン分子が平面内で相対的な回転 運動をすることになり，この回転運動によるスペクトル の分裂は, ベンゼン一窒素の場合に比べてはるかに複雑 になる、これまでのところこれらの内部運動に関する詳 細な解析は発表されていない，完全な解析が完了すれ ば，2つのベンゼンの間の相互作用ポテンシャルに関 し，詳しい知見が得られると期待される.

等核 2 原子分子である酸素分子や窒素分子と希ガス との分子間錯体も興味深い系である. 先に挙げたアセチ レンや, $\mathrm{CO}_{2}$ のような多原子分子を含む無極性分子錯 体の純回転遷移の観測も, 誘起双極子が小さいため極性 分子を含む錯体の場合に比べれば困難であるがここれら の系に関しては，これらの分子が赤外域に許容な振動乇 ードを持つので, 振動回転スペクトルの観測が比較的容 易に実行できる.これに対し，酸素分子や窒素分子のよ うな等核 2 原子分子は, 赤外領域に許容な遷移を持た ないので，マイクロ波領域での誘起双極子による純回転 スペクトルの観測が，これらの系に関する精密な分子定 数を得るほぼ唯一の方法である. そのため, 無極性分子 同土の錯体の分光の中でも，このような系の純回転スペ クトルの観測は特に重要である. 
希ガスー窒素分子のスペクトルは, Gerry らのグルー プによって初めて観測された 23 . また, 図10に示すの は, 我々が初めて観測した, $\mathrm{Ar}-\mathrm{O}_{2}$ 分子の純回転スペ クトルである ${ }^{24)}$. 酸素分子の場合は, 電子基底状態が, 開殼の 3 重項であり, スピン分裂が存在する. 超音速 ビームにより冷却されているため, 観測できるのは, 最 もエネルギーの低いスピン成分のみである。 また，不対 電子の存在のため, 観測されたスペクトル線は図に示す ように常磁性を示す。どちらの系も, 安定な配向は, T型であると結論されている.

無極性の分子一分子錯体や，分子一希ガス錯体以外に も, 閉殼の原子一原子錯体も興味深い分光対象である. これらは最も単純な系であるので, 分子間 (原子間) 相 互作用の研究に基本的な重要性があると考えられる.こ のような系は, 分子錯体の中では比較的回転定数が大き くスペクトルも単純なので, これまで水銀一希ガス系, 希ガス一希ガス系などに関して電子スペクトルが観測さ れており, 結合距離や原子間のポテンシャルについて結 果が得られていた。電子スペクトルでは分解能に限界が あるので, より正確に原子間距離を決定し, 相互作用ポ テンシャルに対して詳しい知見を得るために, 純回転又 ペクトルの観測が望をれていた.

図11に示すのはこのような原子・原子 2 量体の純回 転スペクトルの観測された最初の例である $\mathrm{Hg}-\mathrm{Ar}$ 錯体

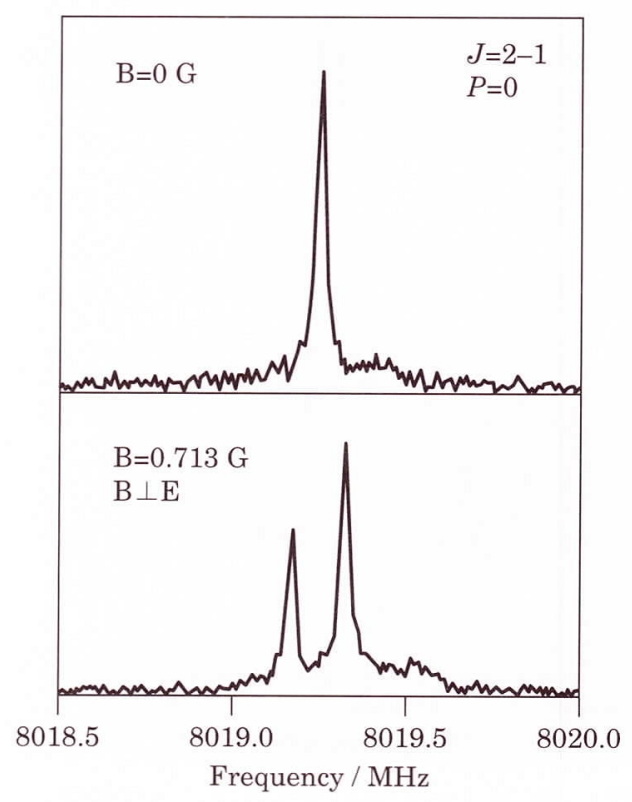

図10 $\mathrm{Ar}-\mathrm{O}_{2}$ のスペクトル。下は磁場をかけた場 合.

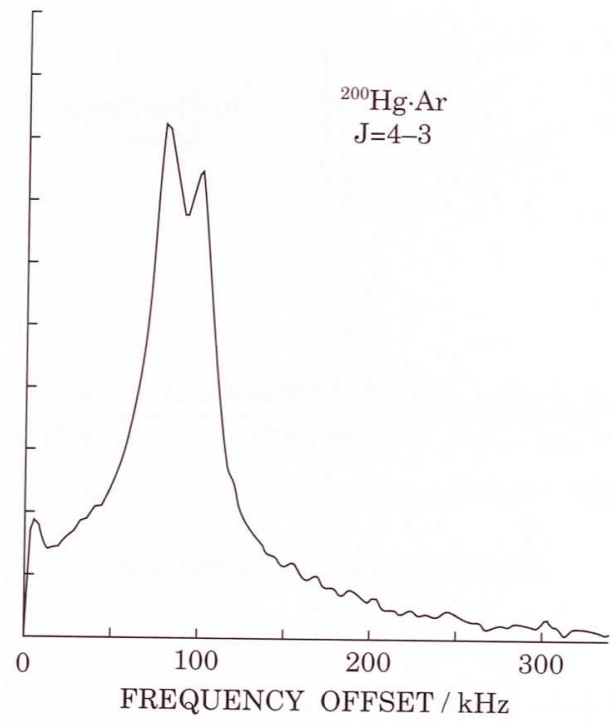

図11原子一原子錯体である水銀- $\mathrm{Ar}$ の純回転スペ クトル (文献25)).

中心周波数7387.759 MHZ, 100回の積算.

のスペクトルである、この錯体の場合にマイクロ波の回 転遷移を与えているのは, ファンデアワールス結合を与 えている分散効果によって誘起されたわずかな双極子七 一メントのみである25). 水銀原子は, 原子としての分 極率がかなり大きく, 分散効果による誘起双極子モ一メ ントもそれなりに大きいと考えられる，その後，同様の 原子. 原子の系として, 希ガス原子同士のファンデアワ 一ルス錯体の純回転スペクトルの観測も報告された26). 特に興味深いのは, Gutowsky 等のグループと NIST の グループにより最近報告された, $\mathrm{Ne}-\mathrm{Ar}$ 錯体のスペク トルである27).この種の錯体としてこれまで純回転ス ペクトルの観測が報告された中では, 最も結合エネルギ 一が小さく, 誘起双極子モーメントも小さいと考えられ る系である. そのため, 期待されるスペクトル強度がこ の種の系としても極めて小さく, フーリエ変換マイクロ 波分光法の感度の限界を試す上でも興味深い。一方，フ アンデアワールス錯体としては比較的総電子数が少な く, 詳しい理論計算との比較が可能であるという点でも この系は重要であると考えられる. 彼らは, 天然の存在 比の最も多い同位体種のみならず, それぞれの原子の様 々な同位体の組み合わせのスペクトルを観測して精度の 高い分子間ポテンシャルを決定した。 また, 双極子モ一 メントが既知の系との比較により，この錯体の双極子モ ーメントを0.0022(5)デバイと見積もっている. 図12に 


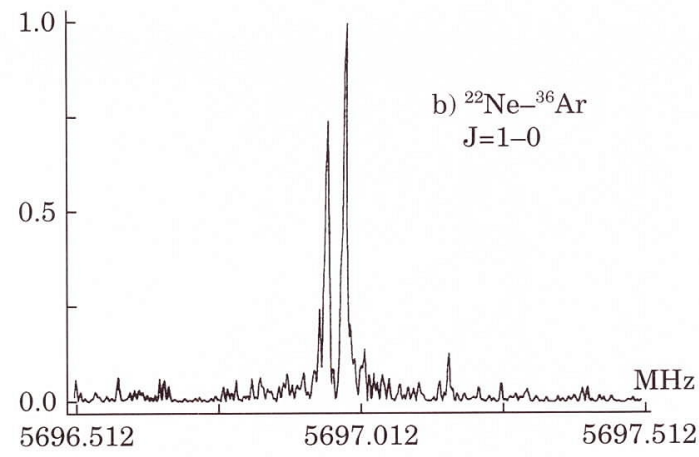

図12 ${ }^{22} \mathrm{Nr}-{ }^{-36} \mathrm{Ar}$ の純回転スペクトル（文献27）よ b). 240,000回の積算結果（観測時間50分）.

示すのは, 自然存在比 $0.03 \%$ の ${ }^{22} \mathrm{Ne}-{ }^{36} \mathrm{Ar}$ のスペクトル である、これたけの S/N を得るのに24万回の積算を行 っている (観測時間50分). 更に, この系では錯体の双 極子モーメントが極めて小さいため, $20 \mathrm{~W}$ の増幅器を 用いて高いマイクロ波の電界により錯体の回転遷移を分 極させて，スペクトルを観測している.

\section{7. 不安定分子の分光}

フーリエ変換マイクロ波分光法がセンチ波の領域で高 い感度を持つことから，不安定分子や分子イオンなどの 分光に対しても有力な分光法であると考えられる.実 際, Flygare 等は, ファブリペロー型の分光器の製作に ついて報告した論文で，この可能性に言及している. 特 に, 超音速ビーム中では, 分子間の衝突がないのでいっ たん生成した不安定分子は, 観測領域（共振器のミラー の間の空間）を飛行している間に反応によって壞れるこ とがないので, 反応性の高い短寿命分子を効率よく検出 できる可能性がある. 問題は, いかにして効率的に不安 定分子を生成し, 超音速ビームとするかという点にあ る.シュタルク分光法に比べれば画期的に感度が高いと はいえ, 充分な $\mathrm{S} / \mathrm{N}$ で信号を観測するにはかなりの量 を効率的に生成する必要がある. 不安定分子を超音速ビ 一ム中に生成し実際に不安定分子の分光が行われるよう になったのは，比較的最近になってからである. 最初に フーリエ変換マイクロ波分光法で不安定分子を観測した のは, NIST の研究グループである. 彼らは, パルスレ 一ザーによるレーザー蒸発法により生成した $\mathrm{SiC}_{2}$ と金 属酸化物の回転スペクトルの観測を報告した ${ }^{28,29)}$. その 後, 同様なレーザー蒸発法により, 金属原子のハロゲン 化物のスペクトルなどの観測が報告されている30).
レーザー蒸発法以外にも不安定分子の生成法として は, 紫外のパルスレーザーによる光解離やパルス放電法 などが考えられる，その中でもパルス放電法は生成可能 な分子種を余り選ばないこと, 装置が簡単で手軽である ことなどから有力な方法であると考えられる. 我々の研 究室では, 1990年頃よりこの方法を用いて不安定分子 の分光を試みていた. 我々が最初に分光対象として取り 上げたのは， $\mathrm{HC}_{9} \mathrm{~N}$ という直線分子である。この分子 は, 1970年代の終わりに電波望遠鏡で星間分子として

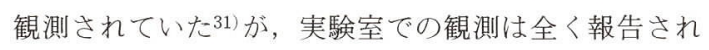
ていなかった。回転定数が約 $290 \mathrm{MHz}$ と極めて小さな 分子であり，他の周波数領域の分光法で精度の高い分光 を行うのは極めて困難であると考えられ, 波長の長いセ ンチ波領域で高い感度を持つフーリ工変換マイクロ波分 光法で取り上げる対象として絶好の分子であると考え た. パルスノズルの先端に電極を取り付け，アクリロニ トリルとアセチレンを $\mathrm{Ar}$ 中に希釈した混合気体を放電 したところ， $\mathrm{HC}_{3} \mathrm{~N}$ や $\mathrm{HC}_{5} \mathrm{~N}, \mathrm{HC}_{7} \mathrm{~N}$ などのスペクトル をかなり強く観測できた. 電極の形状や, 放電のタイミ ング, 試料ガスの濃度などを様々に変えて試したとこ ろ，最終的に図13に示すようなスペクトルを観測でき た、電波望遠鏡のデータから、この吸収線を直ちに

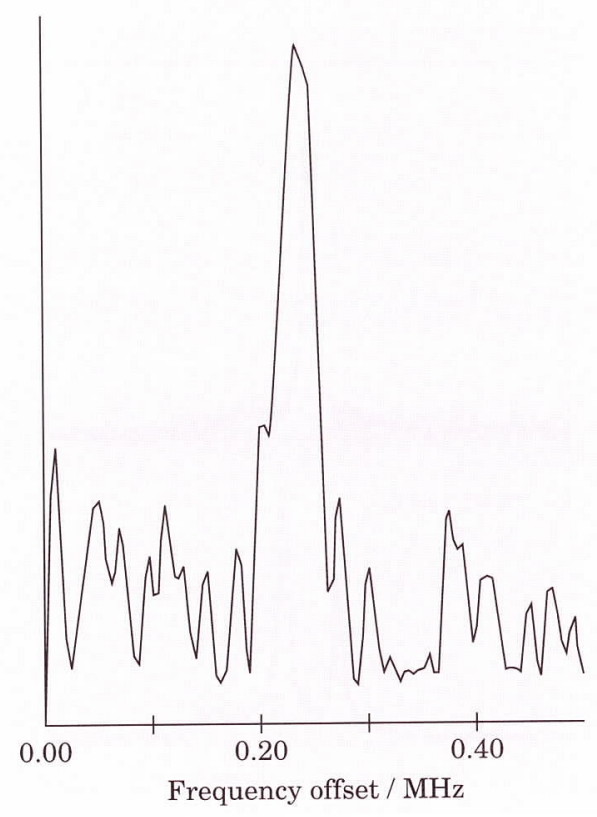

図13 $\mathrm{HC}_{9} \mathrm{~N}, \mathrm{~J}=12-11$ のスペクトル（文献32）よ り). 中心周波数6972.194 MHz, 400回の積算. 
$\mathrm{HC}_{9} \mathrm{~N}$ のスペクトルであると帰属できた。このときに用 いた電極を図14に示す ${ }^{32}$.

その後, 電極の形状を更に改良することで, 様々な不 安定分子を生成し，分光することができるようになっ た. 我々が，この方法で分光した不安定分子の一覧を表 1 に示す，最初にスペクトルを観測した $\mathrm{HC}_{9} \mathrm{~N}$ が典型的 な例であるが，特に長い炭素鎖を持つ分子種が数多く観 測できているのが特徵である。比較的短期間の間にこの ように数多くの新しい分子種を見つけだすことができた ことは，フーリエ変換マイクロ波分光法がこれまでにな い新しい可能性を持つ分光法であることを如実に表して

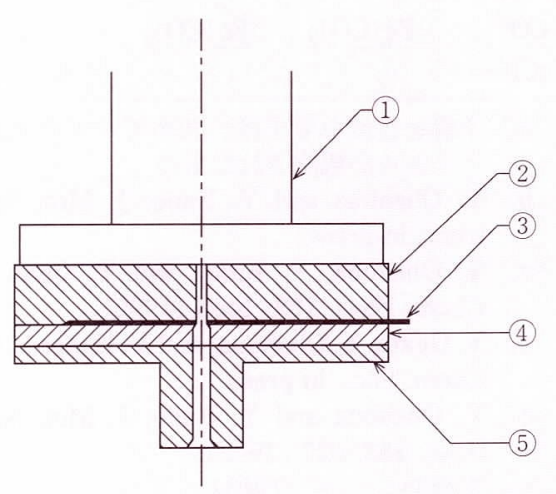

図14 $\mathrm{HC}_{9} \mathrm{~N}$ の分光に使用したパルス放電ノズル. それぞれ，(1)は電磁バルブ，(2)はアクリル の絶縁スペーサ, (3)は陽極, (5)は陰極, (4) はテフロン製のスペーサである。
いる. 特に, 超音速ビームにより極低温に冷却された分 子を分光しているため, 原子数が多い分子でも低い振動 励起状態のスペクトルなどに悩まされることなくスペク トルを観測できることは，この分光法の大きな利点であ る. 又, パルス的な生成を行っているため，後続反応に よる安定生成物のスペクトルによる妨害が比較的少な く，帰属が容易な点も新しい分子種を見つけだすのに適 している。例えば，図15に示すのはアセチレンと 2 硫 化炭素の混合気体を放電し，広い範囲を掃引した得たス ペクトルであるが，観測された吸収線のかなり多くを全 く新しい分子種として帰属することができた ${ }^{4,33,34)}$.こ のようにして見つけだされた分子の多くは，星間分子と しての存在が考えられており, 今後の電波望遠鏡でのス ペクトルの観測が期待されている.

このようにパルス放電ノズルの使用で単体の不安定分 子を超音速ビーム中で効率よく生成でき，そのスペクト ルをフーリエ変換マイクロ波分光で非常に良い S/Nで 観測できることが明らかになったことから，更に一歩を 進めて不安定分子を含む分子錯体の分光の可能性孔生ま れてきた。これまでには, 開殼のラジカル錯体は, もっ ぱらレーザー分光法により観測されてきていた．分子錯 体の回転定数は, 一般に同程度の原子数の単体分子に比 ベずっと小さな值を取ることから，レーザー分光では分 解能が不足して精度の高い分子定数を求めることが困難 である．不安定分子錯体の分子間相互作用についてより 詳しい知見を得るためには, レーザー分光法より分解能 の高い分光法が適用できることが望まれていた.

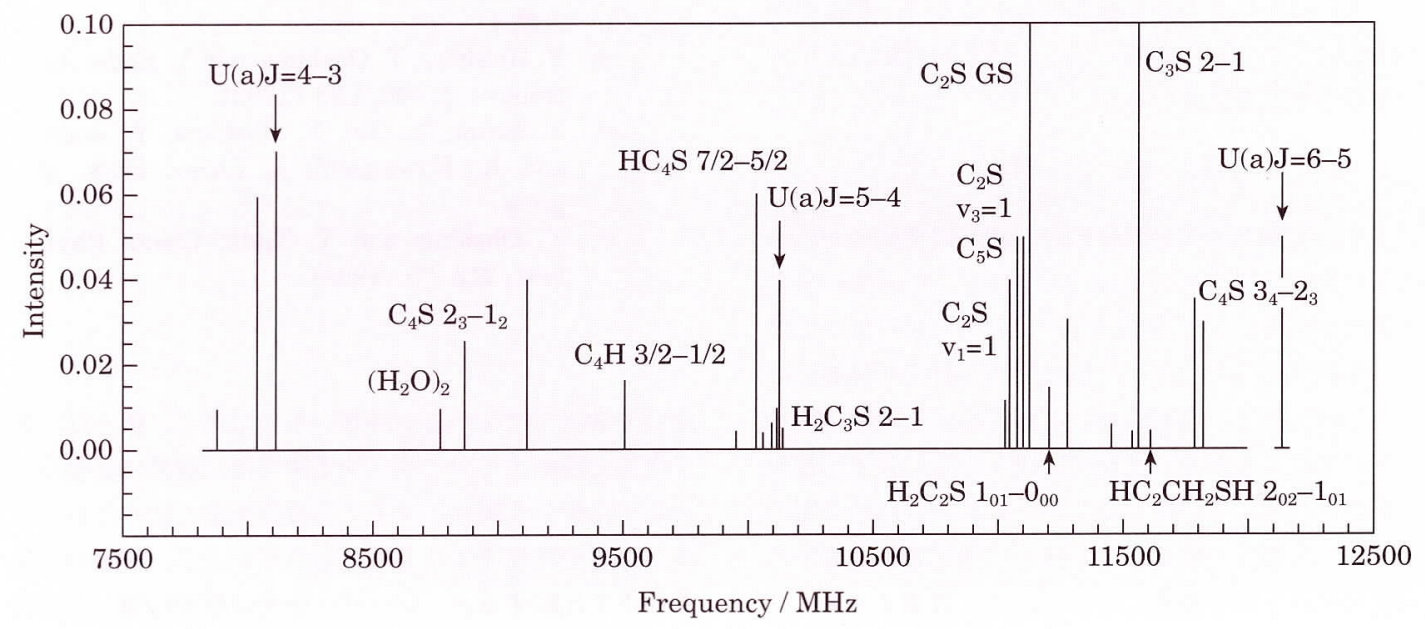

図15 $\mathrm{CS}_{2}$ と $\mathrm{C}_{2} \mathrm{H}_{2}$ の混合気体の放電生成物を広い範囲にわたって分光したスペクトル。この中に新 しいラジカル種として $\mathrm{C}_{4} \mathrm{~S}, \mathrm{C}_{5} \mathrm{~S}, \mathrm{HC}_{3} \mathrm{~S}, \mathrm{HC}_{4} \mathrm{~S}$ を見出した. 
(1995)

我々は，パルス放電ノズルを装備したフーリエ変換マ イクロ波分光器により, 不安定分子錯体として, $\mathrm{Ar}$

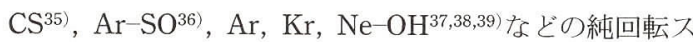
ペクトルを観測した．このうち CS, SO を含む系は，マ イクロ波分光により初めて観測されたものである. 一方, $\mathrm{OH}$ を含む錯体は, $\mathrm{OH}$ ラジカルが, 近紫外域に強い吸 収を持つことから、レーザー萤光法による分光がかなり 精力的に行われてきていた。 マイクロ波分光法は，これ らレーザー分光に比べはるかに高い分解能を持つので, これらかなり詳しく研究が行われていた系に対しても， 新しい知見を得るこができた．その代表的なものに，基 底状態で観測されるパリティ分裂と，水素核の超微細相 互作用分裂がある.これらの観測は，共に開殼のラジカ ル錯体に特有のもので, 希ガスと $\mathrm{OH}$ ラジカルの相互 作用ポテンシャルの決定に大きな寄与をするものであ る.

パルス放電法は放電直後の状態を比較的保ったまま, 超音速ビームを作り出すことができるので, 装置の感度 が充分にあれば，実験条件を最適化することで電荷を持 った分子イオンの分光も可能である。実際，我々は $\mathrm{HCO}_{2}^{+}$や, $\mathrm{HOCS}^{+}, \mathrm{Ar}-\mathrm{D}_{3}^{+}$等の純回転スペクトルをこ の方法で観測することができた $\mathrm{D}_{3}^{+}$は，イオンクラスターと呼べるもので，すでにミり 波。サブミリ波分光により放電プラズマ中で回転スペク トルが観測されていだ1). しかし，定常的な放電プラ ズマ中にイオンクラスターが観測されたのは，この系に 特有の事情によるものであり，他のイオンクラスターの 分光に適用できるものではなかった．フーリエ変換マイ クロ波分光法により超音速ビーム中でこのようなイオン クラスターのスペクトルが観測できたことは，更に他の 系の回転スペクトルの観測に関し, 将来の可能性を示す ものであろうと考えている。

\section{8. まと め}

フーリエ変換マイクロ波分光法, 特に超音速ビーム法 と組み合わせることのできるファブリーペロー型の分光 器が Flygare 等により発表されてから，10年余りにな るが, 本稿で述べたように，最近数年の研究の発展には 著しいものがある．当初はもっぱら安定分子の錯体の分 光に利用されてきたが，現在では様々な系の分光に積極 的に適用されるようになっている. それと共に分光器の 感度の向上も著しく向上している.この分光法は分子の 純回転スペクトルを観測しているので，観測する系・分 子がたとえ極めてわずかでも双極子モーメントを持てば スペクトルの観測が可能である.そのような汎用性は，
表 1 我々の研究室でこれ来でに分光した不安定 分子の一覧

\begin{tabular}{|c|c|c|c|}
\hline $\mathrm{C}_{3} \mathrm{H}$ & $\mathrm{C}_{4} \mathrm{H}$ & $\mathrm{C}_{5} \mathrm{H}$ & $\mathrm{C}_{6} \mathrm{H}$ \\
\hline $\mathrm{CCN}^{\mathrm{b})}$ & $\mathrm{C}_{3} \mathrm{~N}$ & & \\
\hline$\overline{\mathrm{CCO}}$ & $\underline{\mathrm{C}_{4} \mathrm{O}^{\mathrm{c}}}$ & $\underline{\mathrm{C}_{6} \mathrm{O}^{\mathrm{c}}}$ & ${\underline{\mathrm{C}_{8} \mathrm{O}^{\mathrm{c}}}}$ \\
\hline $\mathrm{C}_{3} \mathrm{O}$ & $\overline{\left.\mathrm{C}_{5} \mathrm{O}^{\mathrm{d}}\right)}$ & $\overline{\left.\mathrm{C}_{7} \mathrm{O}^{\mathrm{d}}\right)}$ & $\mathrm{C}_{9} \mathrm{O}^{\mathrm{d})}$ \\
\hline $\mathrm{C}_{2} \mathrm{~S}$ & $\mathrm{C}_{3} \mathrm{~S}^{\mathrm{e}}$ & $\overline{\mathrm{C}_{4} \mathrm{~S}^{\mathrm{f}}}$ & $\overline{\left.\mathrm{C}_{5} \mathrm{~S}^{\mathrm{g}}\right)}$ \\
\hline \multicolumn{4}{|l|}{$\mathrm{HCCN}^{\mathrm{h})}$} \\
\hline $\mathrm{HC}_{3} \mathrm{~N}$ & $\mathrm{HC}_{5} \mathrm{~N}$ & $\mathrm{HC}_{7} \mathrm{~N}$ & $\underline{\left.\mathrm{HC}_{9} \mathrm{~N}^{\mathrm{i}}\right)}$ \\
\hline $\mathrm{HCCO}^{\mathrm{I}}$ & $\mathrm{HC}_{3} \mathrm{O}$ & $\underline{\mathrm{HC}}_{4} \mathrm{O}^{\mathrm{k})}$ & \\
\hline HCCS & $\mathrm{HC}_{3} \mathrm{~S}^{\mathrm{l}}$ & $\overline{\mathrm{HC}_{4} \mathrm{~S}^{1}}$ & \\
\hline \multicolumn{4}{|l|}{$\mathrm{HNC}_{3}{ }^{\mathrm{m})}$} \\
\hline \multicolumn{4}{|l|}{$\mathrm{CH}_{3} \mathrm{CO}$} \\
\hline \multicolumn{4}{|l|}{$\mathrm{H}_{2} \mathrm{C}_{3} \mathrm{H}$} \\
\hline $\mathrm{FeCO}^{\mathrm{n})}$ & $\mathrm{Fe}(\mathrm{CO})_{3}$ & $\mathrm{Fe}(\mathrm{CO})_{4}$ & \\
\hline
\end{tabular}

注）a.下線を付けた分子は，初めてマイクロ波ス ペクトルが観測されたもの

b. Y. Ohshima and Y. Endo: J. Mol. Spectrosc. in press.

c. Y. Ohshima, Y. Endo, and T. Ogata: J. Chem. Phys. 102, 1493 (1995).

d. T. Ogata, Y. Ohshima, and Y. Endo: J. Am. Chem. Soc., in press.

e. Y. Ohshima and Y. Endo: J. Mol. Spectrosc. 153, 627 (1992).

f. 文献33) g. 文献34)

h. Y. Endo and Y. Ohshima: J. Chem. Phys. 98, 6618 (1993).

i. 文献32)

j. Y. Ohshima and Y. Endo: J. Mol. Spectrosc. 159, 458 (1993).

k. H. Kohguchi, Y. Ohshima, and Y. Endo: J. Chem. Phys. 101, 6463 (1994.

1. 文献 4)

m. Y. Hirahara, Y. Ohshima, and Y. Endo: Astrophys. J. 403, L83 (1993).

n. Y. Kasai, K. Obi, Y. Ohshima, Y. Endo, and K. Kawaguchi: J. Chem. Phys. in press.

o. Y. Ohshima and Y. Endo: Chem. Phys. Lett. 213, 95 (1993).

他の分光法ではなかなか得難いものである，例えば，電 子遷移を観測するレーザー分光法では, 観測に必要な分 子数で比較した場合, マイクロ波分光法に比べはるかに 高い感度を実現できると考えられているが，実際の実験 条件下で比較すると，レーザー分光は観測に適した波長 域に強い電子遷移のある系でないと高い感度の分光がで きない，一方，分子の振動回転遷移を観測する赤外のレ 
一ザー分光法と比較した場合, 現在のところ, 特に超音 速ビーム中の分子錯体や不安定分子の分光では, マイク ロ波分光法の方がより高い感度を実現しているように思 われる。

マイクロ波分光法の欠点の一つに，広い周波数領域を 短時間に観測するのが困難であることが挙げられる．特 に, ファブリーペロー型のフーリ工変換マイクロ波分光 法では 1 回の測定で $1 \mathrm{MHz}$ 程度の領域しか観測でき ず，分光に必要な一定の領域をカバーするには，この狭 い領域の観測を繰り返すより他に方法がない，広い領域 の掃引に伴う煩雑さはしかし，装置全体をコンピュータ 制御することでかなり緩和され，現在では数千 $\mathrm{MHz}$ の 領域をもらさず測定することもそれほど困難なことでは ない.さらに，この分光法が純回転スペクトルを観測す る分光法であることから, 観測対象となる分子の構造が 程々の精度で予測できれば，遷移が期待される周波数領 域の見当が容易に付けられる，そのため，周波数掃引の 困難さが実際にこの分光法の可能性を制約することはほ とんど無い.

このような特徴を持つことから, 今後とも更に装置が 改良され, 装置の性能が向上するのに従って, 様々な新 しい系のスペクトルが観測されていくであろうと期待さ れる。

\section{参考文献}

1) J. Ekkers and W. H. Flygare: Rev. Sci. Instrum. 47, 448 (1976).

2) T. J. Balle and W. H. Flygare: Rev. Sci. Instrum. 52, 33 (1981).

3) F. J. Lovas and R. D. Suenram: J. Chem. Phys. 87, 2010 (1987).

4) Y. Hirahara, Y. Ohshima, and Y. Endo: J. Chem. Phys. 101, 7342 (1994).

5) C. Chuang, C. J. Hawley, T. Emilsson, and H. S. Gutowsky: Rev. Sci. Instrum. 61, 1629 (1990).

6) Y. Xu, W. Jaeger, and M. C. L. Gerry: J. Mol. Spectrosc. 151, 206 (1992).

7) U. Andersen, H. Dreizler, J.-U. Grabow, and W. Stahl: Rev. Sci. Instrum. 61, 3694 (1990).

8) E. Arunan and H. S. Gutowsky: J. Chem. Phys. 98, 4294 (1993).

9) J.-U. Brabow and W. Stahl: Z. Naturforsch. A45, 1043 (1990).

10) T. J. Balle, E. J. Campbell, M. R. Keenan, and W. H. Flygare: J. Chem. Phys. 72, 922 (1980).

11) H. S. Gutowsky, T. D. Klots, C. Chuang, C. A. Schmuttenmaer, and T. Emilsson: J. Chem. Phys. 86, 569 (1987).

12) H. S. Gutowsky, C. Chuang, T. D. Kots, T. Emilsson, R. S. Ruoff, and K. R. Krause: J. Chem.
Phys. 88, 2919 (1988).

13) R. S. Ruoff, T. Emilsson, T. D. Klots, C. Chuang, and H. S. Gutowsky: J. Chem. Phys. 89, 138 (1988).

14) E. Arunan, T. Emilsson, and H. S. Gutowsky: J. Am. Chem. Soc. 116, 8418 (1994).

15) G. T. Fraser, A. S. Pine, and R. D. Suenram: J. Chem. Phys. 88, 6157 (1988).

16) M. Iida, Y. Ohshima, and Y. Endo: J. Chem. Phys. 95, 4772 (1991).

17) M. Iida, Y. Ohshima, and Y. Endo: J. Phys. Chem. 97, 357 (1993).

18) Y. Ohshima, M. Iida, and Y. Endo: Chem. Phys. Lett. 161, 202 (1989).

19) R. L. deLeon and J. S. Muenter: J. Chem. Phys. 72, 6020 (1980).

20) Th. Brupbacher and A. Bauder: Chem. Phys. Lett. 173, 435 (1990).

21) Y. Ohshima, H. Kohguchi, and Y. Endo: Chem. Phys. Lett. 184, 21 (1991).

22) J. M. Steed, T. A. Dixon, and W. Klemperer: J. Chem. Phys. 70, 4940 (1979).

23) W. Jaeger and M. C. L. Gerry: Chem. Phys. Lett. 196, 274 (1992).

24) Y. Ohshima, F. Yamuchi, and Y. Endo: to be published.

25) Y. Ohshima, M. Iida, and Y. Endo: J. Chem. Phys. 92, 3990 (1990).

26) W. Jaeger, X. Xu, and M. C. L. Gerry: J. Chem. Phys. 99, 919 (1993).

27) J.-U. Grabow, A. S. Pine, G. T. Fraser, F. J. Lovas, R. D. Suenram, T. Emilsson, E. Arunan, and H. S. Gutowsky: J. Chem. Phys. 102, 1181 (1995).

28) R. D. Suenram, F. J. Lovas, and K. Matsumura: Astrophys. J. 342, L103 (1989).

29) R. D. Suenram, F. J. Lovas, G. T. Fraser, and K. Matsumura: J. Chem. Phys. 92, 4724 (1990).

30) K. D. Hensel, C. Styger, W. Jaeger, A. L. Meter, and M. C. L. Gerry: J. Chem. Phys. 99, 3320 (1993).

31) N. W. Broten, T. Oka, L. W. Avery, J. M. MacLeod, and H. W. Kroto: Astrophys. J. 223, L105 (1978).

32) M. Iida, Y. Ohshima, and Y. Endo, Astrophys. J. 371, L45 (1991).

33) Y. Hirahara, Y. Ohshima, and Y. Endo: Astrophys. J. 408, L113 (1993).

34) Y. Kasai, K. Obi, Y. Ohshima, Y. Hirahara, Y. Endo, K. Kawaguchi, and A. Murakami: Astrophys. J. 410, L45 (1993).

35) H. Kohguchi, Y. Ohshima, and Y. Endo: to be published.

36) H. Kohguchi, Y. Ohshima, and Y. Endo: to be published.

37) Y. Ohshima, M. Iida, and Y. Endo: J. Chem. Phys. 95, 7001 (1991). 
(1995)

38) K. Sato, Y. Ohshima, and Y. Endo: to be published.

39) K. Sato, Y. Ohshima, and Y. Endo: to be published.
40) Y. Ohshima and Y. Y. Endo: to be published.

41) M. Bogey, H. Bolvin, C. Demuynck, and J. L. Destombes: Phys. Rev. Lett. 58, 988 (1987). 